\title{
PENDIDIKAN PONDOK PESANTREN TAHFIZUL QUR'AN DALAM UPAYA PEMBERDAYAAN HAFIZ-HAFIZOH QORI-QORIAH
}

\author{
Sumarto \\ Sekolah Tinggi Agama Islam Ma'arif Jambi \\ sumarto.manajemeno@gmail.com
}

\begin{abstract}
Abstrak
Proses pendidikan yang terarah akan membawa bangsa ini menuju peradaban yang lebih baik. Sebaliknya, proses pendidikan yang tidak terarah, hanya akan menyita waktu, tenaga, serta dana tanpa ada hasil. Dengan demikian, sistem pendidikan sebagai implementasi pendidikan nasional sangat menentukan maju mundurnya bangsa ini. Progam pendidikan menghafal al-Qur'an adalah program menghafal al-Qur'an dengan mutqin (hafalan yang kuat) terhadap lafadz-lafadz al-Qur'an dan menghafal maknamaknanya dengan kuat yang memudahkan untuk menghadirkannya setiap menghadapi berbagai masalah kehidupan, karena al-Qur'an senantiasa ada dan hidup di dalam hati sepanjang waktu, sehingga memudahkan untuk menerapkan dan mengamalkannya. Menghafal alQur'an bukanlah tugas yang mudah, sederhana, serta bisa dilakukan kebanyakan orang tanpa meluangkan waktu khusus, kesungguhan mengerahkan kemampuan dan keseriusan, karena menghafal al-Qur'an merupakan tugas yang sangat agung dan besar. Tidak ada yang sanggup yang melakukannya selain Ulul 'Azmi, yakni orang-orang yang bertekad kuat dan bulat serta keinginan membaja. Hal ini dikarenakan banyak problematika yang harus dihadapi para penghafal al-Qur'an untuk mencapai derajat yang tinggi di sisi Allah SWT. Mulai dari pengembangan minat, penciptaan lingkungan, pembagian waktu sampai kepada metode menghafal itu sendiri. Para penghafal al-Qur'an juga banyak yang mengeluh bahwa menghafal itu susah. Hal ini disebabkan karena adanya gangguan-gangguan, baik gangguan-gangguan kejiwaan maupun gangguan lingkungan.
\end{abstract}

Kata Kunci: Pendidikan, Pondok Pesantren, Tahfizul Qur'an, Pemberdayaan

\section{A. PENDAHULUAN}

Sistem Pendidikan Nasional Nomor

20 Tahun 2003 dan Badan Standar Nasional Pendidikan yang menyatakan bahwa pendidikan nasional bertujuan untuk mengembangkan potensi peserta didik agar menjadi manusia yang beriman dan bertaqwa, berakhlak mulia, sehat, berilmu, cakap kreatif, mandiri dan menjadi warga negara yang demokratis serta bertanggung jawab. ${ }^{1}$

Pendidikan di era reformasi menghadapi dua tuntutan. Pertama adalah tutuntan masyarakat terhadap mutu pendidikan yang rendah dan belum relevan dengan perkembangan masyarakat. Kedua, problema dalam mengembangkan kualitas manusia

\footnotetext{
${ }^{1}$ Sistem Pendidikan Nasional Nomor. 20 Tahun 2003 dan Badan Standar Nasional Pendidikan (BSNP).
} 
manusia sebagai sumber daya yang berkualitas dan professional. Siagian mengatakan manusia tidak mungkin dapat diperlakukan sama dengan alat produksi lainnya, melainkan harus diperlakukan sesuai harkat dan martabatnya. ${ }^{2}$

Arus globalisasi juga telah membawa dampak atau pengaruh negatif pada tatanan kehidupan suatu bangsa. Indonesia sebagai bangsa yang besar, kini diperhadapkan pada berbagai persoalan pembangunan yang tak kunjung selesai, selain itu bangsa ini juga harus memikul dan membangun secara sungguh-sungguh pada berbagai bidang yakni; bidang keamanan dan ketertiban masyarakat, bidang perekonomian untuk kesejahteraan rakyat Indonesia secara lebih merata dan bidang pendidikan dalam membangun sumber daya manusia. ${ }^{3}$ Selain itu dengan adanya Dengan adanya globalisasi akan timbul pemikiran, usulan dan usaha serta kemampuan di seluruh dunia yang dengan sangat cepat dan mudah untuk diakses sehingga dapat memberikan kesempatan baru bagi peneliti atau ilmuwan untuk menganalisis, mengadopsi berbagai bentuk kegiatan pendidikan ${ }^{4}$. Pemerintah untuk melakukan suatu upaya peningkatan kualitas sumber daya manusia yang sejalan dengan pembangunan dan cita-cita

2 Sondang P. Siagian., Manajemen Sumber Daya Manusia, (Jakarta: Bumi Aksara, 2014), h. 39.

3 Sudarman, Peningkatan Profesionalisme Tenaga Pengajar Sebagai Kontribusi Peningkatan Mutu Pembelajaran (Jurnal Pendidikan Inovatif Volume 3, 2007), h.11.

${ }^{4}$ M. Ihsan Dacholfany, Reformasi Pendidikan Islam dalam Menghadapi Era Globalisasi: Sebuah Tantangan dan Harapan, Jurnal Akademika, Vol. 20, no. 01 Jan - Juni, 2015, h. 174 bangsa. ${ }^{5}$ Karena pentingnya upaya peningkatan sumber daya manusia maka hal itu menjadi tanggung jawab bersama, pemerintah maupun masyarakat. ${ }^{6}$

Tujuan pendidikan dan tujuan belajar meliputi tiga aspek, yaitu: Aspek kognitif, aspek afektif dan aspek psikomotorik, sampai saat ini, faktor yang paling berpengaruh terhadap hasil belajar dari ketiga aspek tersebut adalah aspek kognitif yang meliputi persepsi, ingatan dan berfikir sedangkan aspek afektif dan psikomotorik lebih bersikap pelengkap untuk menentukan derajat keberhasilan belajar anak di sekolah. ${ }^{?}$

Bila ditelusuri lebih lanjut, tujuan dari penddikan adalah terwujudnya insan kamil atau insan yang sempurna baik dari segi intelektual maupun prilakunya. Menghafal Al-Qur'an merupakan bahagian dari tujuan pendidikan terutama dalam menanamkan akhlak yang mulia. Al-Qur'an adalah firman Allah yang tidak terdapat kebatilan di dalamnya, dan alQur'an adalah mu'jizat terbesar dan kekal bagi Rasullulah SAW. Allah SWT sudah memerintahkan agar menjaganya dari perubahan dan penggantian. ${ }^{8}$ Allah swt berfirman :

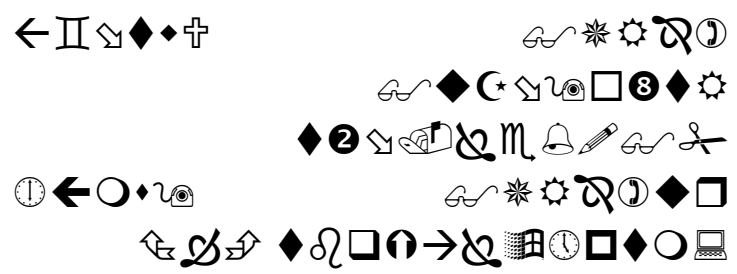

${ }^{5}$ Wina Sanjaya, Pembelajaran \& Implementasinya (Jakarta: Prenada Media, 2005), h. 35

${ }^{6}$ H. A. R Tilaar, Kekuasaan dan Pendidikan: Manajemen Pendidikan Nasional dalam Pusaran Kekuasaan (Jakarta: Rineka Cipta, 2009), h. 50.

7 Abu Ahmadi, Startegi Belajar Mengajar (Bandung Pustaka Setia.2005), h.110-111.

8 Abdurrab Nawabudin, Teknik Menghafal AlQur'an, (Bandung : Sinar Baru, 1991), Cet.1, h.12. 
Artinya:

"Sesungguhnya Kami-lah yang menurunkan Al-Qur'an, dan Sesungguhnya Kami benar-benar memeliharanya." (Q.S Al-hijr : 9). ${ }^{9}$

Dan Nabi Shallallahu 'alaihi wa sallam bersabda: ... Dan tidaklah sebuah kaum berkumpul disalah satu rumah dari rumah-rumah Allah, mereka membaca Kitabullah, dan mempelajari Sunnah Nabi mereka, kecuali akan diturunkan kepada mereka ketenangan, dan mereka akan diliputi dengan rahmat Allah, para malaikat akan mengelilingi mereka, dan Allah akan menyebut-menyebut mereka kepada malaikat yang berada disisi-Nya. ${ }^{10}$ Dan beliau Shallallahu 'alaihi wa sallam bersabda: Dan sebaik-baik di antara kalian adalah yang mempelajari Al-Qur`an dan mengajarkannya. ${ }^{11}$ Dan beliau Shallallahu 'alaihi wa sallam bersabda: Seorang yang fasih dalam membaca Al-Qur`an akan bersama dengan para malaikat yang mulia dan berbakti dan yang membaca AlQur`an dengan terbata-bata, dan dia kesulitan dalam membacanya, maka baginya dua pahala. ${ }^{12}$

Al-Qur'an yang ada sekarang ini masih asli dan murni sesuai dengan apa yang diajarkan oleh Nabi Muhammad SAW kepada para sahabatnya, hal itu karena Allah-lah yang menjaga. Penjagaan Allah kepada al-Qur'an bukan berarti Allah menjaga secara langsung fase-fase penulisan al-Qur'an, tetapi Allah

9 Departemen Agama RI, Al-Qur'an dan Terjemahnya, (Jakarta:Toha Putra, t. th), h. 391.

10 Diriwayatkan oleh Muslim (2699)

11 Diriwayatkan oleh Al-Bukhari (5027)

12 Diriwayatkan oleh Al-Bukhari (4937) dan Muslim (798) dan lafazh diatas lafazh pada riwayat Muslim. melibatkan para hamba-Nya untuk ikut menjaga al-Qur'an. ${ }^{13}$

Dari ayat tersebut yang membuat banyak umat islam yang ingin menghafalkan al-Qur'an demi keutuhan al-Qur'an itu sendiri. Menghafal al-Qur'an boleh dikatakan sebagai langkah awal dalam suatu proses penelitian akbar yang dilakukan oleh para penghafal al- Qur'an dalam memahami kandungan ilmu-ilmu al-Qur'an, tentunya setelah proses dasar membaca al-Qur'an dengan baik dan benar, akan tetapi ada juga yang sebaliknya, yaitu belajar isi kandungan alQur'an terlebih dahulu kemudian menghafalnya. ${ }^{14}$

Progam pendidikan menghafal alQur'an adalah program menghafal alQur'an dengan mutqin (hafalan yang kuat) terhadap lafadz-lafadz al-Qur'an dan menghafal makna-maknanya dengan kuat yang memudahkan untuk menghadirkannya setiap menghadapi berbagai masalah kehidupan, karena alQur'an senantiasa ada dan hidup di dalam hati sepanjang waktu, sehingga memudahkan untuk menerapkan dan mengamalkannya. ${ }^{15}$

Menghafal al-Qur'an tidak semudah membalikkan telapak tangan. Kerumitan di dalamnya yang menyangkut ketepatan membaca dan pengucapan tidak bisa diabaikan begitu saja, sebab kesalahan sedikit saja adalah suatu dosa. Apabila hal tersebut dibiarkan dan tidak diproteksi secara ketat maka kemurnian al-Qur'an

13 Ahsin Sakho Muhammad, Kiat-Kiat Menghafal Al-Qur'an, (Jawa Barat : Badan Koordinasi TKQ-TPQ-TQA, t.th), h, 3.

${ }^{14}$ Ahsin W., Bimbingan Praktis Menghafal AlQur'an, (Jakarta : Bumi Aksara, 2000), h, 19.

${ }^{15}$ Khalid bin Abdul Karim Al-Lahim, Mengapa Saya Menghafal Al-Qur'an, (Surakarta : Daar AnNaba', 2008), h. 19. 
menjadi tidak terjaga dalam setiap aspeknya. ${ }^{16}$

Sudah dimaklumi bersama dan sudah sangat jelas, bahwa menghafal alQur'an bukanlah tugas yang mudah, sederhana, serta bisa dilakukan kebanyakan orang tanpa meluangkan waktu khusus, kesungguhan mengerahkan kemampuan dan keseriusan $^{17}$, karena menghafal al-Qur'an merupakan tugas yang sangat agung dan besar. Tidak ada yang sanggup yang melakukannya selain Ulul 'Azmi, yakni orang-orang yang bertekad kuat dan bulat serta keinginan membaja. ${ }^{18}$ Kiranya tidak berlebihan jika dikatakan bahwa menghafal al-Qur'an itu berat dan melelahkan.

Hal ini dikarenakan banyak problematika yang harus dihadapi para penghafal al-Qur'an untuk mencapai derajat yang tinggi di sisi Allah SWT. Mulai dari pengembangan minat, penciptaan lingkungan, pembagian waktu sampai kepada metode menghafal itu sendiri. ${ }^{19}$ Para penghafal al-Qur'an juga banyak yang mengeluh bahwa menghafal itu susah. Hal ini disebabkan karena adanya gangguan-gangguan, baik gangguan-gangguan kejiwaan maupun gangguan lingkungan. ${ }^{20}$

Masing-masing di antara umat Islam tentu saja bercita-cita untuk menghafal al-

${ }^{16}$ Abdul Aziz Abdul Rauf, Kiat Sukses menjadi Hafidz Qur'an Da'iyah, (Bandung: Syaamil Cipta Media, 2004), Cet. 4, h. 40

17 Raghib As-Sirjani, Cara Cerdas Hafal AlQur'an, (Solo : Aqwam, 2007), Cet. 1, hal. 53.

18 8M. Taqiyul Islam Qori, Cara Mudah Menghafal Al-Qur'an, (Jakarta : Gema Insani, 1998), h. 63.

${ }^{19}$ Op. Cit., Ahsin W, h.41

20 Muhaimin Wazin Zenha, Pedoman Pembinaan Tahfidzul Qur;an, (Jakarta : Proyek Penerangan, Bimbingan dan da'wah/Khutbah Agama Islam Pusat Ditjen Bimas Islam dan Urusan Haji Depag RI, 1982), h., 43.
Qur'an. Setiap orang juga merasakan semangat dan merasakan bahwa sebenarnya mampu menghafalnya dengan cara konsisten, menghafal surat demi surat, juz demi juz. Namun setelah itu, mulailah berbagai bisikan dan gangguan batin membuat orang tersebut malas dan semangat semakin mengendor dengan alasan banyak surat yang mirip, kata-kata yang sulit, waktu sempit, dan banyak kesibukan. ${ }^{21}$ Menghafal al-Qur'an berbeda dengan menghafal buku atau kamus.

Al-Qur'an adalah kalamullah, yang akan mengangkat derajat mereka yang menghafalnya ${ }^{22}$, oleh karena itu para penghafal al-Qur'an perlu mengetahui halhal atau upaya agar mutu hafalannya tetap terjaga dengan baik. Allah SWT berfirman dalam al-Qur'an :

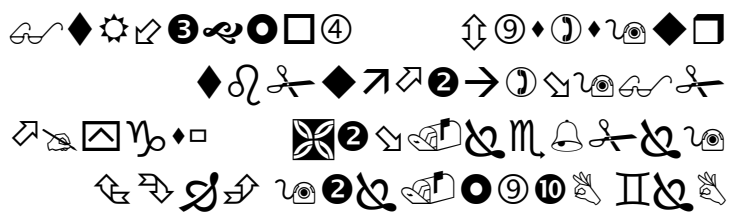

Artinya:

Dan sesungguhnya telah Kami mudahkan Al-Quran untuk pelajaran, Maka adakah orang yang mengambil pelajaran?" (Q.S. Al-Qamar :17). ${ }^{23}$

Maksudnya, Allah akan memberi kemudahan kepada orang-orang yang ingin menghafalnya. Jika ada di kalangan manusia yang berusaha untuk menghafalnya, maka Allah akan memberi pertolongan dan kemudahan baginya. ${ }^{24}$ Proses menghafal al-Qur'an adalah mudah dari pada memeliharanya. Banyak

21 Haya Ar-Rasyid dan Shalih bin Fauzan, Keajaiban Belajar Al-Qur'an, (Solo : Al- Qowam, 2007), h.47.

${ }^{22}$ Op. Cit., Abdul Aziz Abdul Rauf, h., 55.

${ }_{23}$ Op. Cit., Al-Qur'an Al-Karim dan Terjemahnya, h.879.

24 Hasan bin Ahmad bin Hasan Hamam, Menghafal al-Qur'an Itu Mudah, (Jakarta : AtTazkia, 2008), h, 13. 
penghafal al-Qur'an yang mengeluh karena semula hafalannya baik dan lancar, tetapi pada suatu saat hafalan tersebut hilang dari ingatannya. Hal ini dapat terjadi karena tidak ada pemeliharaan. Oleh karena itu untuk meningkatkan hafalan al-Qur'an harus mempunyai cara-cara yang tepat, sehingga hafalan al-Qur'an tersebut akan bertambah lebih baik.

Dari penjelasan di atas, penulis akan melakukan penelitian tentang permasalahan di atas, anatar lain adalah:

1. Bagaimana perbedaan antara penghafal al-Qur'an berbeda dengan penghafal hadits, sya'ir, hikmah dan lain-lainnya ?

2. Bagaimana Cara Memberdayakan Hafiz Hafizoh dan Qori Qoriah ?

\section{B. KAJIAN TEORI}

\section{Pendidikan Pondok Pesantren Tahfizul Qur'an (Prespektif Manajemen/Pengelolaan)}

Secara etimologi, manajemen berasal dari bahasa Inggris, kata to manage, dalam Webster's New Collegiate Dictionary, kata manage dijelaskan berasal dari bahasa Italia "managgio" dari kata "managgiare" dan kata ini berasal dari bahasa Latin manus yang berarti tangan (hand). Kata manage dalam kamus tersebut diberi arti: membimbing dan mengawasi, memperlakukan dengan seksama, mengurus perniagaan atau urusan-urusan, mencapai tujuan tertentu. ${ }^{25}$

Manajemen adalah suatu proses atau kerangka kerja yang melibatkan bimbingan atau pengarahan suatu kelompok orang-orang kearah tujuantujuan organisasional atau maksudmaksud yang nyata. Manajemen adalah

${ }^{25}$ Husni Rahim, Arah Baru Pendidikan Islam di Indonesia (Jakarta: Logos, 2004), hal. 37. suatu kegiatan, pelaksanaannya adalah managing (pengelolaan), sedang pelaksananya disebut manager atau pengelola. $^{26}$

Manajemen merupakan suatu istilah yang mempunyai banyak arti, bergantung kepada orang yang mengartikannya. Istilah manajemen acapkali diartikan sebagai suatu pengelolaan, yaitu pengelolaan yang dilandaskan pada keahlian guru mencapai suatu profesi manajer dan para profesional dituntut oleh suatu kode etik sehingga dengan ini istilah manajemen dipandang sebagai suatu profesi. $^{27}$

Manajemen menurut Malayu S.P Hasibuan adalah ilmu seni mengatur proses pemanfaatan sumber daya manusia dan sumber-sumber lainnya secara efektif dan efesien untuk mencapai suatu tujuan tertentu. Manajemen menurut G.R Terry adalah suatu proses yang khas yang terdiri dari tindakan-tindakan perencanaan, pengorganisasian, pengarahan dan pengendalian yang dilakukan untuk menentukan serta mencapai sasaransasaran yang telah ditentukan melalui pemanfaatan sumber daya manusia dan sumber-sumber lainnya. Menurut Harold Koontz dan Cyril O’Donnel, manajemen adalah usaha untuk mencapai suatu tujuan tertentu melalui kegiatan orang lain. ${ }^{28}$ Sedangkan manajemen pendidikan merupakan proses manajemen dalam pelaksanaan tugas pendidikan dengan mendayagunakan segala sumber secara

${ }^{26}$ George R. Terry dan Leslie W. Rue, DasarDasar Manajemen (Jakarta: Bumi Aksara), 2012, h. 1 .

27 Tim Penyusun Kamus Pusat Bahasa, Kamus Besar Bahasa Indonesia (Jakarta: Balai Pustaka, 2002), h. 708.

${ }^{28}$ Malayu S.P. Hasibuan, Manajemen Dasar, Pengertian dan Masalah (Jakarta: Bumi Aksara, 2009), h. 2-3. 
efesien untuk mencapai tujuan secara efektif. $^{29}$

Secara terminologi, ada beberapa definisi mengenai manajemen, diantaranya yang dikemukakan oleh R.C. Devis: management is the function of executive leadership anywhere. Manajemen itu merupakan fungsi dari kepemimpinan eksekutif pada organisasi apa pun. William Spriegel: management is that function of an enterprise which concerns with the direction and control of the various activities to attain the business objectives. Di sini Spriegel memandang manajemen sebagai kegiatan perusahaan (yang mestinya dapat diterapkan bagi kegiatan non-perusahaan juga).

Setiap pondok pesntren memiliki tujuan. Tujuan akan tercapai apabila dilaksanakan dengan manajemen yang baik termasuk perencanaan, strategi dirancang dari perencanaan yang tersusun dengan rapi karena perencanaan adalah proses penentuan tujuan atau sasaran yang hendak dicapai dan menetapkan jalan dan sumber yang diperlukan untuk mencapai tujuan itu seefesien dan seefektif mungkin. Dalam setiap perencanaan ada tiga kegiatan yaitu perumusan tujuan yang hendak dicapai, pemilihan program untuk mencapai tujuan itu dan identifikasi dan pengerahan sumber yang jumlahnya selalu terbatas $^{30}$

Untuk mencapai tujuan dibutuhkan pemimpin. Proses memimpin atau disebut juga kepemimpinan yaitu sebagai kemampuan seseorang atau pemimpin,

29 Tim Guru Administrasi Pendidikan Universitas Pendidikan Indonesia, Manajemen Pendidikan (Bandung: Alfabeta, 2014), Cet. Ke-7, h. 87.

30 Nanang Fattah, Landasan Manajemen Pendidikan (Bandung: Remaja Rosdakarya, 2013), Cet. Ke-12, h. 49. untuk mempengaruhi perilaku orang lain menurut keinginan-keinginannya dalam suatu keadaan tertentu. Kepemimpinan merupakan suatu pertumbuhan alami dari orang-orang yang berserikat untuk suatu tujuan dalam suatu kelompok. ${ }^{31}$

Pembahasan kegiatan Manajemen dapat ditemui dalam banyak literatur ilmiah. Uraian berikut ini tidak bermaksud untuk melakukan pembahasan yang serupa. Dengan kata lain uraian ini difokuskan pada pembahasan tentang manajemen pondok pesantren Tahfizul Qur'an yang mendukung pelaksanaan Manajemen, sedangkan manajemen sebagai suatu proses pelaksanaan administrasi dalam suatu organisasi, merupakan aktifitas yang continuous (terus-menerus) mulai dari perencanaan sampai penilaian. Dalam proses pelaksanaannya manajemen pendidikan fungsi mempunyai tugas-tugas yang harus diselesaikan, dalam manajemen kita kenal sebagai fungsi, yaitu:

Perencanaan pada hakikatnya adalah aktifitas pengambilan keputusan tentang sasaran apa yang akan dicapainya, tindakan apa yang akan diambil dalam rangka mencapai tujuan atau sasaran tersebut dan siapa yang akan melaksanakan tugas tersebut. Sebagaimana fungsi-fungsi manajemen yang lainnya, istilah perencanaan juga mempunyai bermacam-macam pengertian sesuai dengan pendapat para ahli manajemen.

Sujana mengemukakan, bahwa perencanaan merupakan proses yang sistematis dalam pengambilan keputusan tentang tindakan yang akan dilakukan

${ }^{31}$ George R. Terry dan Leslie W. Rue, DasarDasar Manajemen (Jakarta: Bumi Aksara), 2005, h. 192. 
pada waktu yang akan datang. Disebut sistematis karena perencanaan dilaksanakan dengan menggunakan prinsip-prinsip tertentu. Prinsip-prinsip tersebut mencakup proses pengambilan keputusan, penggunaan pengetahuan dan teknik secara ilmiah, serta tindakan atau kegiatan yang terorganisasi.

Sepanjang

perkembangannya, pengorganisasian atau sebagai fungsi manajemen, memiliki pengertian yang berbeda-beda. Pengertian tersebut disebabkan oleh perbedaan latar belakang keahlian para pakar yang memberikan pengertian itu, dan dipengaruhi oleh kondisi lingkungan dalam menerapkan fungsi pengorganisasian tersebut. Istilah organisasi dapat diartikan ke dalam dua pengertian yaitu: dalam arti statis, organisasi sebagai wadah kerja sama sekelompok orang yang bekerja sama, untuk mencapai tujuan tertentu.

Dalam arti dinamis, organisasi sebagai suatu system atau kegiatan sekelompok orang untuk mencapai tujuan tertentu. Nanang Fattah mengemukakan, pengertian pertama organisasi diartikan sebagai suatu lembaga atau kelompok fungsional, misalnya sebuah perusahaan, sebuah sekolah, sebuah perkumpulan, badan-badan pemerintahan. Kedua, merujuk pada proses pengorganisasian yaitu bagaimana pekerjaan diatur dan dialokasikan di antara para anggota, sehingga tujuan organisasi dapat tercapai secara efektif.

Untuk melaksanakan basil perencanaan dan pengorganisasian maka perlu diadakan tindakan kegiatan yang actuating (penggerakan). Actuating adalah salah satu fungsi manajemen yang sangat penting sebab tanpa fungsi ini, maka apa yang telah direncanakan dan diorganisir itu tidak dapat direalisasikan dalam kenyataan.

Dalam mendefinisikan actuating adalah upaya untuk menggerakkan atau mengarahkan man power (tenaga kerja) serta mendayagunakan fasilitas yang ada yang bukan berupa manusiawi. Pengerahan tenaga kerja serta pendayagunaan berbagai fasilitas di atas dimaksud untuk melaksanakan pekerjaan bersama.

Untuk melaksanakan basil perencanaan dan pengorganisasian maka perlu diadakan tindakan kegiatan yang actuating (penggerakan). Actuating adalah salah satu fungsi manajemen yang sangat penting sebab tanpa fungsi ini, maka apa yang telah direncanakan dan diorganisir itu tidak dapat direalisasikan dalam kenyataan. Sedangkan mendefinisikan actuating adalah upaya untuk menggerakkan atau mengarahkan man power (tenaga kerja) serta mendayagunakan fasilitas yang ada yang bukan berupa manusiawi. Pengerahan tenaga kerja serta pendayagunaan berbagai fasilitas di atas dimaksud untuk melaksanakan pekerjaan bersama.

Menurut Sukanto Reksohadiprojo, pengawasan pada hakikatnya merupakan usaha memberi petunjuk pada para pelaksana agar mereka selalu bertindak sesuai dengan rencana. Lebih lanjut dikatakan bahwa pengawasan itu terdiri dari penentuan-penentuan standar, supervisi kegiatan atau pemeriksaan, pembandingan hasil dengan standar serta kegiatan mengoreksi kegiatan atau standar. ${ }^{32}$

${ }^{32}$ Henry L. Sisk, Principles of Management: A System Approach to the Management Process (England: South-Western Publishing Company, 1999), h.. 10. 
Tahfidz al-Qur'an terdiri dari dua suku kata, yaitu tahfidz dan al-Qur'an, yang mana keduanya mempunyai arti yang berbeda. Pertama tahfidz yang berarti menghafal, menghafal dari kata dasar hafal yang dari bahasa arab hafidzayahfadzu-hifdzan, yaitu lawan dari lupa, yaitu selalu ingat dan sedikit lupa. ${ }^{33}$

Menurut Abdul Aziz Abdul Ra'uf definisi menghafal adalah "proses mengulang sesuatu, baik dengan membaca atau mendengar". Pekerjaan apapun jika sering diulang, pasti menjadi hafal." 34 Menurut Ibnu Madzkur yang dikutip dalam buku Teknik Menghafal al-Qur'an karangan Abdurrab Nawabudin berkata bahwa menghafal adalah orang yang selalu menekuni pekerjaannya, ${ }^{35}$ pernyataan ini merujuk pada al-Qur'an surat al-Baqarah ayat 238:

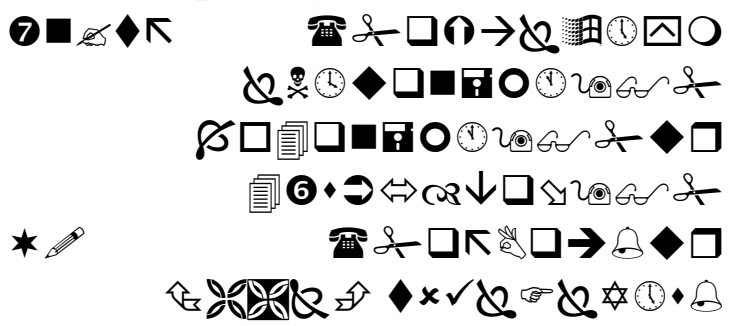

Artinya: Peliharalah semua shalat(mu), dan (peliharalah) shalat wusthaa ${ }^{36}$. Berdirilah untuk Allah (dalam shalatmu) dengan khusyu'. (QS: Al-Baqarah: 238) ${ }^{37}$

Maksudnya, shalatlah tepat pada waktunya. Menghafal sesuatu, yaitu

33 Mahmud Yunus, Kamus Arab-Indonesia, (Jakarta : Hidakarya Agung, 1990), h, 105.

${ }^{34}$ Abdul Aziz Abdul Rauf, Kiat Sukses Menjadi Hafizh Qur'an Da'iyah, (Bandung : PT Syaamil Cipta Media, 2004), Cet, 4, h.49.

35 Abdurrab Nawabudin, Teknik Menghafal alQur'an, (Bandung : Sinar Baru, 1991), cet, 1, h.23.

${ }^{36}$ Shalat wusthaa ialah shalat yang di tengahtengah dan yang paling utama. ada yang berpendapat, bahwa yang dimaksud dengan shalat wusthaa ialah shalat Ashar. menurut kebanyakan ahli hadits, ayat ini menekankan agar semua shalat itu dikerjakan dengan sebaik-baiknya.

37 Departemen Agama RI, Al-Qur'an dan Terjemahnya, (Jakarta: Toha Ptra, t. th), h. 400. mengungkapkan satu demi satu dengan tepat. $^{38}$ Kata-kata hifdz dalam al-Qur'an dapat berarti banyak hal, sesuai dengan pemahaman konteks, sebagaimana firman Allah dalam Surat Yusuf ayat 65 :

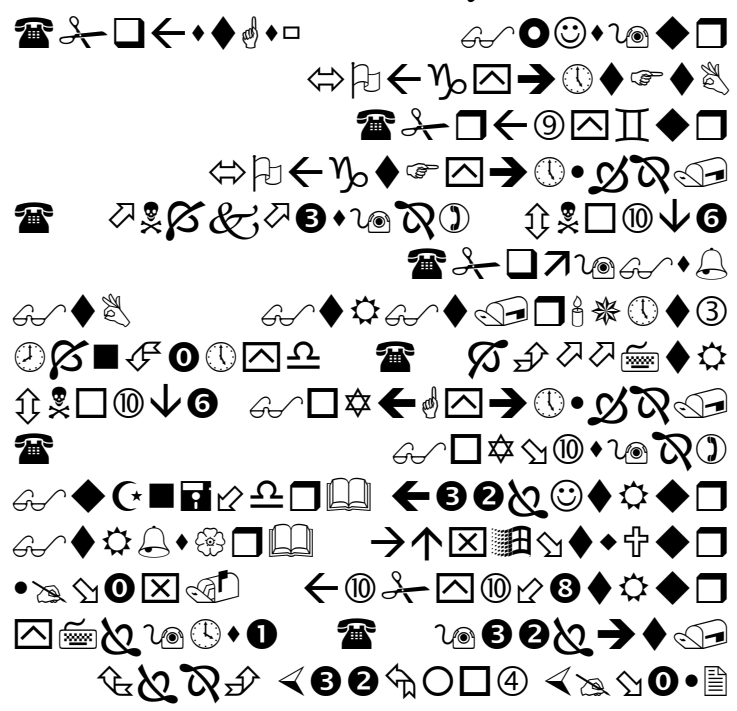
Artinya:

Tatkala mereka membuka barangbarangnya, mereka menemukan kembali barang-barang (penukaran) mereka, dikembalikan kepada mereka. mereka berkata: "Wahai ayah Kami apa lagi yang kita inginkan. ini barang-barang kita dikembalikan kepada kita, dan Kami akan dapat memberi Makan keluarga Kami, dan Kami akan dapat memelihara saudara Kami, dan Kami akan mendapat tambahan sukatan (gandum) seberat beban seekor unta. itu adalah sukatan yang mudah (bagi raja Mesir)". (QS : Yusuf : 65). ${ }^{39}$

Di sini berarti menahan diri yang tidak dihalalkan Allah SWT. Dalam surat al-Anbiya' ayat 32 Allah berfirman :

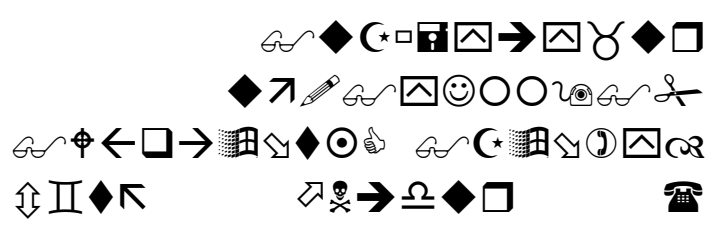

${ }^{38}$ Op. Cit, Abdurrab Nawabudin, h, 23-24

39 Op. Cit. Al-Qur'an Al-Karim dan Terjemahnya, h, 876 . 


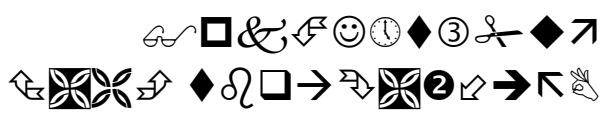

Artinya: dan Kami menjadikan langit itu sebagai atap yang terpelihara ${ }^{40}$, sedang mereka berpaling dari segala tandatanda (kekuasaan Allah) yang terdapat padanya. (QS : Al-Anbiya' : 32).

\section{PEMBAHASAN}

1. Hafidzh di sini artinya mengangkat atau menggantung

Banyaknya makna al-Hifdz dalam al-Qur'an pada dasarnya terletak pada konteks apa makna tersebut yang digunakan, yaitu seperti contoh ayat di atas yang maknanya berbeda-beda, ada yang bermakna menjaga, menahan menggantung, dan lain-lain sesuai dengan konteks kalimatnya. Jika arti bahasa hafal tidak berbeda dengan arti istilah dari segi membaca di luar kepala.

Penghafal al-Qur'an berbeda dengan penghafal hadits, sya'ir, hikmah dan lainlainnya dalam 2 pokok :

a. Hafal seluruh al-Qur'an serta mencocokannya dengan sempurna.

Tidak bisa disebut al-hafidz bagi orang yang hafalannya setengah atau sepertiganya secara rasional. Karena jika yang hafal setengah atau sepertiganya berpredikat al-hafidz, maka bisa dikatakan bahwa seluruh umat Islam berpredikat al-hafidz, sebab semuanya mungkin telah hafal surat alfatihah, karena surat al-Fatih merupakan salah satu rukun shalat dari kebanyakan madzhab. Maka istilah

40 Maksudnya: yang ada di langit itu sebagai atap dan yang dimaksud dengan terpelihara ialah segala yang berada di langit itu dijaga oleh Allah dengan peraturan dan hukum-hukum yang menyebabkan dapat berjalannya dengan teratur dan tertib. alhafidz (orang yang berpredikat hafal Qur'an) adalah mutlak bagi yang hafal keseluruhan dengan mencocokan dan menyempurnakan hafalannya menurut aturan-aturan bacaan serta dasar-dasar tajwid yang masyhur.

b. Senantiasa terus menerus dan sungguhsungguh dalam menjaga hafalan dari lupa Seorang hafidz harus hafal alQur'an seluruhnya. Maka apabila ada orang yang telah hafal kemudian lupa atau lupa sebagian atau keseluruhan karena lalai atau lengah tanpa alasan seperti ketuaan atau sakit, maka tidak dikatakan hafidz dan tidak berhak menyandang pedikat"penghafal alQur'an". ${ }^{41}$

Kedua kata al-Qur'an, menurut bahasa al-Qur'an berasal dari kata $q a$ $r a-a$ yang artinya membaca9, para ulama' berbeda pendapat mengenai pengertian atau definisi tentang alQur'an. Hal ini terkait sekali dengan masing-masing fungsi dari al-Qur'an itu sendiri. Menurut Asy-Syafi'i, lafadz al-Qur'an itu bukan musytaq, yaitu bukan pecahan dari akar kata manapun dan bukan pula berhamzah, yaitu tanpa tambahan huruf hamzah di tengahnya. Sehingga membaca lafazh al-Qur'an dengan tidak membunyikan "a".

Menurut Asy-syafi'i lafadz tersebut sudah lazim digunakan dalam pengertian kalamullah yang diturunkan kepada Nabi Muhammad saw. ${ }^{42}$ Berarti menurut pendapatnya bahwa lafazh alQur'an bukan berasal dari akar kata qaraa yang artinya membaca. Sebab kalau akar katanya setengah atau sepertiganya

41 Abdu al-Rabb Nawabudin, Metode Efektif Menghafal al-Qur'an, (Jakarta : CV Tri Daya Inti, 1988), h, 17

42 Adnan Mahmud Hamid Laonso, Ulumul Qur'an, (Jakarta : Restu Ilahi,2005), h,1. 
berpredikat al-hafidz, maka bisa dikatakan bahwa seluruh umat Islam berpredikat al-hafidz, sebab semuanya mungkin telah hafal surat al-fatihah, karena surat al-Fatih merupakan salah satu rukun shalat dari kebanyakan madzhab, maka istilah alhafidz (orang yang berpredikat hafal Qur'an) adalah mutlak bagi yang hafal keseluruhan dengan mencocokan dan menyempurnakan hafalannya menurut aturan-aturan bacaan serta dasar-dasar tajwid yang masyhur.

Adapun pengertian Manajemen pondok pesantren tahfizul qur'an dalam penelitian ini berdasarkan uraian teori yang disampaikan adalah tindakantindakan perencanaan, pengorganisasian, pengarahan dan pengendalian yang dilakukan untuk menentukan serta mencapai sasaransasaran yang telah ditentukan melalui pemanfaatan sumber daya manusia dan sumber-sumber lainnya dalam hal ini memberdayakan potensi santri dalam menghafal Al Qur'an dan para qori dan qoriah. Indikatornya adalah adanya pengelolaan dengan proses mengulang sesuatu, baik dengan membaca atau mendengar dan selalu menekuninya.

\section{Pemberdayaan Hafiz-Hafizoh dan} Qori'-Qori'ah

Pada dasarnya pemberdayaan adalah cara untuk melaksanakan kerjasama dalam organisasi sehingga semua orang berpartisipasi penuh. Dalam organisasi yang sudah diberdayakan para pelaksana (guru, teknisi, pegawai administrasi, pustakawan, laboran, dan sebagainya) merasa bertanggung-jawab tidak hanya tentang pekerjaan yang dikerjakannya, tetapi juga tentang keseluruhan perguruan tingginya agar dapat berfungsi secara lebih baik. $^{43}$

Pemberdayaan hafiz hafizoh dengan penerapan adab menghafal Al Qur'an yaitu dengan cara memperhatikan niat ikhlas di saat mempelajari Al-Qur`an dan ketika membacanya. Dikarenakan membaca Al-Qur`an adalah ibadah yang dengan ibadah tersebut bertujuan untuk bertemu dengan wajah Allah. Setiap amal ibadah untuk mendekatkan diri kepada Allah tanpa disertai dua syarat diterimanya amal yaitu ikhlas dan sesuai tuntunan syariat maka amalan tersebut akan tertolak.

An-Nawawi mengatakan: Yang pertama kali diperintahkan bagi seorang Qari' Al-Qur`an adalah keikhlasan dalam membaca Al-Qur`an, dan hanya menghendaki perjumpaan dengan wajah Allah subhanahu wata'ala dari bacaan AlQur`an tersebut, dan tidak menghendaki pencapaian sesuatu selain itu."44 Yang dikatakan oleh An-Nawawi ini adalah suatu yang benar, karena diantara para Qari' ada yang membaca Al-Qur'an dengan tujuan agar perhatian kaum manusia tertuju kepadanya, dan agar mereka mendatangi majlis-nya, menyanjungnya dan menghormatinya.

Kami memohon kepada Allah keselamatan dan 'afiah. Dan cukuplah sebagai peringatan bagi Qari' tersebut, agar dia mengetahui siksa bagi seseorang yang mempelajari Al-Qur`an agar dikatakan sebagai seorang Qari' AlQur`an. Imam Muslim telah meriwayatkan sebuah hadits didalam kitab Shahih beliau, dari hadits Abu Hurairah radhiallahu

43 Margono Slamet, Jurnal: Pemberdayaan Sumber Daya Manusia adalah Kunci Penting Meraih Mutu Organisasi, 2014.

44 Al-Adzkaar hal. 160 Daar Al-Huda, cet. Ketiga $1410 \mathrm{H}$ 
'anhu, beliau berkata: Saya telah mendengar Rasulullah Shallallahu 'alaihi wa sallam bersabda: “ Sesungguhnya orang yang paling pertama kali dijatuhkan putusannya pada hari kiamat, adalah seseorang yang mati syahid. Lalu diapun didatangkan dan dikabarkan nikmatnikmat baginya lalu diapun mengetahuinya. Allah berfirman kepadanya: "Apakah yang telah engkau kerjakan bagi segala nikmat tersebut? ". Dia menjawab: Saya berperang karena Engkau hingga saya mendapatkan mati syahid.

Allah berfirman: "Engkau telah berdusta, akan tetapi engkau berpernag agar engkau dikatakan sebagai seorang yang gagah berani, dan itu telah dikatakan bagimu". Kemudian diapun dilerintahkan untuk diseret kehadapan wajahnya lalu dia dicampakkan kedalam api neraka. Dan seseorang yang mempelajari ilmu lalu mengajarkannya dan membaca Al-Qur`an. Kemudian dia dihadapkan, dan dikabarkan nikmat-nikmat baginya lalu diapun mengetahuinya. Allah berfirman: “Apakah yang telah engkau kerjakan bagi segala nikmat tersebut? " Dia berkata: Saya mempelajari ilmu dan mengajarannya dan membaca Al-Qur`an karena Engkau. Allah berfirman: "Engkau telah berdusta, akan tetapi engkau mempelajari ilmu agar engkau dikatakan sebagai seorang yang alim, dan engkau membaca Al-Qur`an agar engkau dikatakan sebagai seorang Qari', dan itu telah dikatakan bagimu. Kemudian diapun diperintahkan untuk diseret kehadapan wajahnya lalu dia dicampakkan kedalam api neraka. " alhadist $^{45}$

45 Hadits no. 1905
3. Mengamalkan kandungan Al-Qur`an Yaitu menghalalkan segala yang dihalalkan didalam Al-Qur`an, mengharamkan segala yang diharamkannya, berhenti pada setiap yang dilarangnya, mengerjakan setiap perintahnya dan mengamalkan setiap ayatayatnya yang muhkam dan beriman dengan ayat-ayat yang mutasyabih. Menegakkan setiap hukum-hukumnya dan huruf-hurufnya. Telah ada larangan yang sangat keras bagi seseorang yang Allah berikan kepadanya Al-Qur`an lantas dia tidak mengamalkannya.

Didalam Shahih Al-Bukhari dari penggalan hadits mimpin Nabi Shallallahu 'alaihi wa sallam dari sebuah hadits yang panjang, disebutkan: "Keduanya mengatakan: Pergilah. Maka kamipun beranjak pergi hingga kami menjumpai seseorang yang berbaring terlentang diatas tengkuknya, dan seseorang yang berdiri diatas kepalanya dengan sebuah pemukul atau sebuah batu besar lalu orang itu memecahkan kepala orang yang berbaring tersebut.

Dan sewaktu dia memukulkan batu itu kekepalanya, batu tersebut terguling, kemudian dia pergi mengambil batu tersebut, dan tidaklah dia kembali kepada orang ini hingga kepalanya telah sembuh dan kembali seperti sedia kala, lalu diapun kembali memukulkan batu tersebut kekepalanya. Saya berkata: Siapakah ini? Keduanya mengatakan: Pergilah (Kemudian hal itu ditefsirkan kepada beliau Shallallahu 'alaihi wa sallam, beliau berkata): Dan orang yang engkau lihat kepalanya dipukulkan dengan batu besar, adalah seseorang yang Allah telah ajarkan kepadanya Al-Qur`an, namun dimalam hari dia tidur tidak membacanya dan tidak mengamalkan Al-Qur`an disiang ahrinya, 
akan diperbuat hal demikian pada dirinya pada hari kiamat.

4. Anjuran untuk selalu mengingat AlQur`an dan memperbarui bacaan AlQur`an

Mengingat-ingat

Al-Qur`an

maksudnya adalah dengan membiasakan diri membaca Al-Qur’an dan selalu berupaya mengingatnya. Adapun memperbaruinya adalah dengan memperbaharui untuk konsisten mempelajarinya dan membacanya. ${ }^{46}$ Seseorang yang telah memfokuskan dirinya ntuk menghafal Kitab Allah dan yang telah menghafalkannya, apabila dia tidak menjaganya dengan mempelajari dan mengingat-ingatnya kembali, maka hafalannya dia akan mudah terlupakan. Al-Qur`an sangatlah mudah lepas dari dalam dada, oleh karena itu mesti memperbanyak perhatian dan lebih sering mempelajarinya dan membacanya.

Rasulullah Shallallahu 'alaihi wa sallam telah memberikan sebuah pemisalan bagi kita akan hal seorang penyandang Al-Qur`an yang memperhatikan Al-Qur`an dan seseorang yang melalaikannya. Ibnu Umar radhiallahu 'anhuma telah meriwayatkan bahwa Rasulullah Shallallahu 'alaihi wa sallam bersabda Sesungguhnya pemisalan seorang penyandang Al-Qur`an bagaikan pemilik onta yang lagi terikat. Apabila dia memperhatikannya baik-abik tentu dia akan memegangnya dengan erat namun apabila dia melepaskannya maka onta tersebut akan lari darinya. ${ }^{47}$

46 Lihat didalam Fathul Baari ( 8 / 697 - 699 ), cet. Daar Ar-Rayyan lit-Turats

47 Diriwayatkan oleh Al-Bukhari (5031 dan Muslim 789)
Dan dari hadits Abu Musa radhiallahu 'anhu, beliau berkata : Bahwa Nabi Shallallahu 'alaihi wa sallam bersabda: Jagalah Al-Qur`an, Demi Dzat yang mana jiwaku berada didalam genggaman-Nya, sesungguhnya Al-Qur`an sangat mudah lepas daripada seekor onta yang ebrada dalam ikatannya. ${ }^{48}$ Al-Hafidz Ibnu Hajar mengatakan dalam menerangkan perumpamaan yang disampaikan oleh Nabi Shallallahu 'alaihi wa sallam: Beliau menyerupakan sirnanya Al-Qur'an dengan berangsur-angsur dan kontinyuitas dalam membaca Al-Qur`an seumpama ikatan pada seekor unta yangdikhawatirkan lepas pergi. Kapan penjagaan Al-Qur'an ini ada, maka hafalan Al-Qur`an pun jug tetap ada, sebagaimana halnya seekor unta, kapan unta tersebut diikat erat dengan tali maka unta tersebut akan tetap terjaga. Dan pengkhususan penyebutan unta pada hadits diatas, dikarenakan unta adalah hewan peliharaan manusia yang paling mudah lepas, dan sangatlah sulit untuk menemukan hewan tersebut apabila hewan ini telah lepas ${ }^{49}$.

5. Janganlah anda mengatakan: Saya telah lupa ayat atau surah Al-Qur'an akan tetapi katakanlah: Saya telah terlupakan, terjatuh hafalanku atau dilupakan.

Dalil akan hal itu, ada pada sebuah hadits yang diriwayatkan oleh Ummul Mukminin Aisyah radhiallahu 'anha beliau berkata: Rasulullah Shallallahu 'alaihi wa sallam telah mendengar seseorang yang membaca sebuah surah di dalam AlQur`an pada waktu malam, lalu beliau bersabda: Semoga Allah merahmatinya,

48 Diriwayatkan oleh Al-Bukhari (5033)

49 Fathul Baari 8 / 697, 698 
sungguh dia telah mengingatkan aku akan ayat ini dan ayat ini, yang sebelumnya saya telah terlupakan bahwa ayat tersebut berada pada surah ini dan surah ini. Pada riwayat Muslim lainnya: “... Sungguh dia telah mengingatkan aku sebuah ayat yang saya telah jatuhkan penyebutannya dari surah ini dan surah ini."

Dan pada hadits Abdullah bin Mas'ud, Rasulullah Shallallahu 'alaihi wa sallam bersabda: "alangkah buruknya seseorang diantara mereka yang mengatakan: Saya telah lupa ayat ini dan ayat ini, tetapi sesungguhnya dia telah terlupakan. ${ }^{51}$ An-Nawawi mengatakan: "Pada hadits tersebut, menunjukkan tercelanya perkataan: lupa akan ayat ini, dan celaan ini sifatnya suatu yang makruh, dan perkataan: saya terlupakan bukan suatu yang tercela. Adapun larangan mengatakan: saya lupa ayat ini , dikarenakan mengandung sikap memudahmudahkan dan melailaikan ayat-ayat tersebut. Allah ta'ala berfirman: Dan ayatayat Kami telah datang kepada-mu lalu kamu melupakannya Al-Qadhli 'Iyadh mengatakan: "Penafsiran yang paling tepat terhadap hadits tersebut bahwa maknanya adalah celaan yang ditujukan pada keadaan sipengucap, bukan pada ucapannya, yakni saya lupa keadaan tersebut, keadaan dalam mengahafal AlQur`an lalu diapun lalai hingga melupakannya "52

6. Wajib menghayati kandungan AlQur`an

50 Diriwayatkan oleh Al-Bukhari (5038) dan Muslim ( 788 )

51 Diriwayatkan oleh Al-Bukhari (5039) danMuslim ( 790 )

52 Syarh Muslim (jilid ketiga - 6 / 63), Cet. Daar Al-Fikr.
Sekian banyak nash-nash syara' yang mengharuskan penghayatan kandungan ayat-ayat Al-Qur'an Al'Aziz. Beberapa diantaranya telah dikemukakan sebelumnya, dan juga pada firman Allah ta'ala : " Apakah mereka tidak memikirkan Al-Qur'an. Sekiranya Al-Qur`an datangnya dari selainAllah, niscaya mereka akanmendapatkan perselisihan yang sangat banyak " (An-Nisaa': 82).

Ibnu Sa'diy mengatakan: "Allah ta'ala memerintahkan untuk menghayati Kitab-Nya yaitu dengan menelaah makna-makna yang terkandung didalamnya, memikirkannya lebih mendalam, tentang hal-hal yang prinsipil serta perkara-perkara yang mengikutinya dan hal-hal yang berkaitan erat dengan hal itu, dikarenakan penghayatan akan Kitabullah merupakan kunci pembuka bagi setiap ilmu dan pengetahuan, dan akan menghasilkan setiap kebaikan dan setiap ilmu akan dapat disadur dari Kitab-Nya.

Dengan penghayatan ini akan menambah keamanan didalam hati, dan akan mengokohkan pohon keamanan tersebut, dan dengan itu, akan diketahui Siapakah Ar-Rabb Al-Ma'buud yang disembah dengan haq, beserta sifatsifat-Nya yang sempurna dan sifat-sifat yang kurang mesti dijauhkan dari-Nya. Dan dengan itu juga, akan dikenali jalan yang akan mengantarkan kepadaNya, sifat kaum yang meniti jalan tersebut, dan balasan pahala bagi mereka setelah tiba dihadapan-Nya. Dan juga akan dikenali musuh AlQur`an, musuh Al-Qur`an yang sebenarnya, dan jalan yang akan mengantarkan kepada siksa, dan sifat 
kaum yang berada diatas jalan tersebut, serta apa saja yang ditimpakan bagi mereka disaat sebab-sebab datangnya adzab ada pada mereka, dan setiap kali seorang hamba semakin menelaah kandungan Al-Qur`an, maka akan bertambah ilmu, amal dan keyakinannya, oleh karena itulah Allah ta'ala memeritahkan hal itu, menganjurkanya dan Allah ta'ala telah mengabarkan, bahwa inilah maksud dengan diturunkannya Al-Qur`an, sebagaimana firman Allah ta'ala :

Inilah Kitab yang Kami telah turunkan kepada engkau, kitab yang penuh berkah, agar suapay mereka memperhatikan ayat-ayat-Nya dan agar supaya orang-orang yang berpikir merenunginya " 53 (Shad : 29)

Ulama As-Salaf dari generasi sahabat radhiallahu 'anhum dan generasi setelahnya telah mempraktikkan hal itu dalam amal perbuatan mereka. Imam Ahmad telah meriwayatkan dari Abu Abdirrahman, beliau berkata: Telah menceritakan kepada kami salah seorang sahabat Nabi Shallallahu 'alaihi wa sallam yang membacakan Al-Qur`an kepada kami , bahwa mereka para sahabat mengambil bacaan Al-Qur`an dari Rasulullah Shallallahu 'alaihi wa sallam sebanyak sepuluh ayat, dan mereka tidaklah mengambil sepuluh ayat berikutnya sebelum mereka mengetahui kandungan ilmu dari ayatayat ini kemudian mengamalkannya. Mereka berkata : Maka kami

53 Taisir Al-Karim Ar-Rahman fii Tafsir Kalam Al-Mannan ( 2 / 112 ) cet. Ar-Riasah Al'Ammah li-Idaraat Al-Buhuts Al-'Ilmiyah wa AlIfta'. mempelajari ilmu Al-Qur`an dan mengamalkannya ${ }^{54}$.

Pengecualian dari itu juga, dengan hadits yang diriwayatkan oleh Malik di dalam Al-Muwaththa' beliau dari jalan Yahya bin Sa'id, bahwa beliau berkata: Saya dan Muhammad bin Yahya bin Hibban pernah duduk, lalu Muhammad memanggil seseorang dan mengatakan: Kabarkanlah kepadaku apa yang telah engkau dengan dari bapakmu. Orang itu berkata: Bapaku telah mengabarkan kepadaku bahwa dia telah mendatangi Zaid bin Tsabit, lalu berkata kepadanya: Bagaiman pendapatmu mengenai seseorang yang membaca AlQur`an dalam tujuh hari. Zaid berkata: Suatu yang baik, namun saya membacanya dalam setengah buan atau dalam waktu sepuluh hai lebih saya sukai daripadanya, dan tanyakan kepadaku mengapa demikian? Dia berkata: Saya bertanya kepada engkau? Zaid mengatakan: Agar saya dapat menghayatinya dan memahaminya. ${ }^{55}$

Untuk

melaksankan

pemberdayaan tersebut perlu pencapaian tujuan utama dari pendidikan dan pelatihan itu adalah memberi wawasan yang lebih luas dan dalam tentang hakekat tugas yang diembannya, Mengembangkan penguasaan keterampilan-keterampilan dasar yang relevan dengan jenis tugasnya, memperluas dan memperdalam pengetahuanpengetahuan yang berkaitan dengan tugasnya, serta menanamkan nilai-nilai

54 Al-Musnad ( 22971 )

55 Al-Muwaththa' Malik ( 320 ) (1/ 136) cet. Daar Al-Kitab Al-'Arabi. 
yang terkandung dalam setiap hal yang dipelajarinya.

Dengan wawasan, keterampilan, dan pengetahuan yang selalu bertambah itu diharapkan orang-orang itu akan berkembang kreativitasnya dan berani berinisiatif untuk mencoba cara-cara baru dalam kerjanya. Cara-cara baru itulah yang bisa diharapkan dapat membawa perbaikan dan kemajuan. Tanpa adanya pendidikan dan pelatihan tambahan sulit diharapkan berkembangnya kreativitas dan inisiatif untuk melahirkan dan mencoba caracara baru, dan tanpa cara-cara baru sulit diharapkan adanya mutu kinerja yang lebih baik.

$$
\text { Kepala Pondok Pesantren }
$$

Tahfizul Qur'an menjalankan fungsifungsi manajemen. Manajemen dalam organisasi sekolah merujuk pada proses penggerakan seluruh potensi sumberdaya manusia dan nonmanusia. Manajemen berfungsi untuk menggerakkan berbagai kegiatan organisasi dalam mencapai tujuan. Peran pimpinan dalam menggerakkan organisasi sangat mennetukan keberhasilan pencapaiaan tujuan organisasi yang dipimpinnya. Banyak faktor yang mempengaruhi keberhasilan seorang pemimpin dalam mengelola organisasi. Pertama, akseptasi atau penerimaan dari kelompoknya. Kedua, kafabilitas atau kemampuan pribadinya. Ketiga,kemampuan mendorong dan mengajak orang lain untuk berbuat sesuatu guna mencapai tujuan bersama. Keempat, kemampuan dan penguasaan pengetahuan di bidang manajemen sekolah. ${ }^{56}$

Menurut Saiful Bahri Djamarah dalam Martinis secara keseluruhan guru adalah figur yang menarik perhatian semua orang, entah dalam keluarga, dalam masyarakat atau di sekolah. Tidak seorangpun yang tidak mengenal guru. Hal ini dikarenakan figur guru itu bermacam-macam seperti guru silat, guru mengaji, guru mata pelajaran, dan lain-lain. Ki Hajar Dewantara menyebutkan sosok guru sebagai tut wuri handayani, ing madyo mangun karso, ing ngarso sung tulodo.

Selain itu, guru dalam pendidikan Islam menurut Ahmad Tafsir siapa saja yang bertanggung jawab terhadap perkembangan anak didik. Dalam Islam, orang yang paling bertanggung jawab itu disebabkan sekurangkurangnya oleh dua hak; pertama karena kodrat, yaitu karena orang tua ditakdirkan menjadi orang tua anaknya, dan karena itu dia ditakdirkan pula bertanggung jawab mendidik anaknya; kedua karena kepentingan orang tua, yaitu orang tua berkepentingan terhadap kemajuan perkembangan anaknya, sukses anaknya adalah sukses orang tua juga.

$$
\text { Apapun istilah yang }
$$
dikedepankan tentang figur guru, yang pasti semua itu merupakan penghargaan yang diberikan terhadap jasa guru yang banyak mendidik umat manusia dari dulu hingga sekarang. Masyarakat melihat figur guru sebagai manusia serba bisa tanpa cela dan nista. Mereka

\footnotetext{
${ }^{56}$ Sudarwan Danim dan Suparno, Manajemen dan Kepemimpinan Transformasional Kekepalasekolahan (Jakarta: Rineka Cipta, 2009), hal. 12-15.
} 
melihat guru sebagai figur yang kharismatik. Kemuliaan seorang guru tercermin dari kepribadian sebagai manifestasi dari sikap dan perilaku dari kehidupan sehari-hari. Oleh karena itu sedikit cela dan nista dari pribadi guru maka masyarakat mencaci makinya habis-habisan dan hilanglah wibawa guru itu.

Menurut Mulyasa, semua orang yakin bahwa guru memiliki andil yang sangat besar terhadap keberhasilan pembelajaran di sekolah. Guru sangat berperan dalam membantu perkembangan peserta didik untuk mewujudkan tujuan hidupnya secara optimal. Keyakinan ini muncul karena manusia adalah makhluk lemah, yang dalam perkembangan senantiasa membutuhkan orang lain, sejak lahir bahkan pada saatmeninggal. Semua itu menunjukkan bahwa setiap orang membutuhkan orang lain dalam perkembangannya, demikian halnya peserta didik; ketika orang tua mendaftarkan anaknya ke sekolah pada saat itu juga ia menaruh harapan terhadap guru, agar anaknya dapat berkembang secara optimal.

Minat, bakat, kemampuan, dan potensi-potensi yang dimiliki oleh peserta didik tidak akan berkembang secara optimal tanpa bantuan guru. Dalam kaitan ini guru perlu memperhatikan peserta didik secara individual, karena antara satu peserta didik dengan lainnya memiliki perbedaan yang mendasar.

Memahami uraiaan di atas, betapa besarnya jasa guru dalam membantu pertumbuhan dan perkembangan para peserta didik. Mereka memiliki peran dan fungsi yang sangat penting dalam membentuk kepribadian anak, guna menyiapkan dan mengembangkan sumber daya manusia (SDM), serta mensejahterakan masyarakat, kemajuan negara dan bangsa.

Guru juga harus berpacu dalam pembelajaran, dengan memberikan kemudahan belajar bagi seluruh peserta didik, agar dapat mengembangkan potensinya secara optimal. Dalam hal ini, guru harus kreatif, profesional, dan menyenangkan, dengan memposisikan diri sebagai berikut:

a. Orang tua yang penuh kasih sayang pada peserta didiknya.

b. Teman, tempat mengadu, dan mengutarakan perasaan bagi para peserta didik.

c. Fasilitator yang selalu siap memberikan kemudahan, dan melayani peserta didik sesuai minat, kemampuan, dan bakatnya.

d. Memberikan sumbangan pemikiran kepada orang tua untuk dapat mengetahui permasalahan yang dihadapi anak dan memberikan saran pemecahana.

e. Memupuk rasa percaya diri, berani dan bertanggung jawab.

f. Membiasakan peserta didik untuk saling berhubungan (bersilaturahmi) dengan lain secara wajar.

g. Mengembangkan proses sosialisasi yang wajar antara peserta didik, orang lain, dan lingkungannya.

h. Menjadi pembantu bagi diperlukan. Untuk memenuhi tuntutan di atas, guru harus mampu memaknai pembelajaran serta menjadikan pembelajaran sebagai ajaran pembentukan kompetensi dan perbaikan kualitas pribadi 
peserta didik. ${ }^{57}$ Sedangkan disiplin sangat penting untuk pertumbuhan organisasi, digunakan terutama untuk memotivasi pegawai agar dapat mendisiplinkan diri dalam melaksanakan pekerjaan baik secara perorangan maupun kelompok. Disamping itu disiplin bermanfaat mendidik pegawai untuk mematuhi dan menyenangi peraturan, prosedur, maupun kebijakan yang ada, sehingga dapat menghasilkan kinerja yang baik.

Kurang pengetahuan tentang peraturan, prosedur, dan kebijakan yang ada merupakan penyebab terbanyak tindakan indisipliner. Sebagai contoh salah satu upaya untuk mengatasi hal tersebut pihak pimpinan sebaiknya memberikan program orientasi kepada tenaga perawat atau bidan yang baru pada hari pertama mereka bekerja, karena perawat atau bidan tidak dapat diharapkan bekerja dengan baik dan patuh, apabila peraturan atau prosedur atau kebijakan yang ada tidak diketahui, tidak jelas, atau tidak dijalankan sebagai mestinya Selain memberikan orientasi, pimpinan harus menjelaskan secara rinci peraturan peraturan yang sering dilanggar, berikut rasional dan konsekwensinya. Demikian pula peraturan/prosedur atau kebijakan yang mengalami perubahan atau diperbaharui, sebaiknya diinformasikan kepada staf melalui diskusi aktif.

Perintah membaca yang merupakan bahagian dari proses pebelajran yang harus selalu diawasi dan diamati oleh kepala sekolah sebagai bentuk penerapan kedisiplinan belajar yaitu membaca dalam

${ }^{57}$ Martinis Yamin dan Maisah, Manajemen Pembelajaran Kelas (Strategi Meningkatkan Mutu Pembelajaran) (Jakarta: Gaung Persada, 2012), h.100-102.
Al Qur'an yaitu dalam surat Al-Alaq ayat $1-5$ :

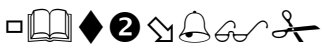

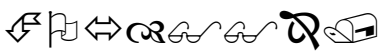

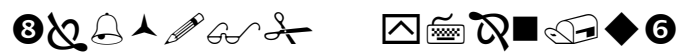

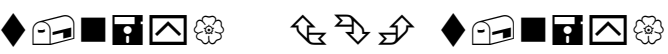

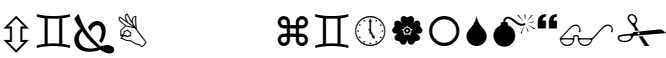

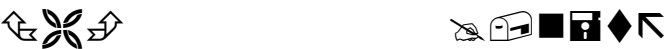

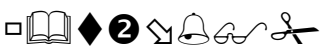

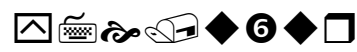

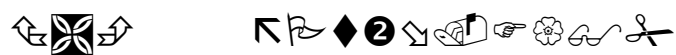

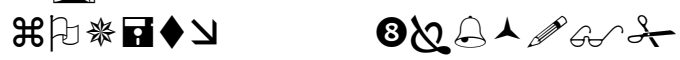

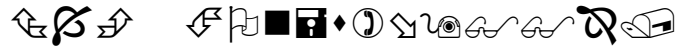

$$
\begin{aligned}
& \text { भII (1) O० }
\end{aligned}
$$

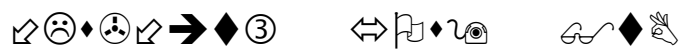

$$
\begin{aligned}
& \text { 仓िर्य }
\end{aligned}
$$

Artinya:

Bacalah dengan (menyebut) nama Tuhanmu yang Menciptakan, Dia telah menciptakan manusia dari segumpal darah. Bacalah, dan Tuhanmulah yang Maha pemurah, yang mengajar (manusia) dengan perantaran kalam ${ }^{58}$, Dia mengajar kepada manusia apa yang tidak diketahuinya.

Dapat disimpulkan pemberdayaan merupakan cara untuk melaksanakan kerjasama dalam organisasi sehingga semua orang berpartisipasi penuh. Dalam organisasi yang sudah diberdayakan para pelaksana (guru, teknisi, pegawai administrasi, pustakawan, laboran, dan sebagainya) merasa bertanggung-jawab tidak hanya tentang pekerjaan yang dikerjakannya, tetapi juga tentang keseluruhan perguruan tingginya agar dapat berfungsi secara lebih baik.

\section{Kesimpulan}

Santri yang sudah menghafal Al Qur'an banyak diantara meraka yang

58 Maksudnya: Allah mengajar manusia dengan perantaraan tulis baca. 
mengalami lupa terhadap apa yang sudah dihafalnya. Selain itu ketika menghafal Al Qur'an mereka merasa kesulitan tetapi harus meraka hafal juga karena sudah menjadi tuntutan dari pondok pesantren tersebut, sehingga mereka merasa terpaksa untuk menghafal Al Qur'an, ketika mereka sudah menghafal Al Qur'an, apa yang dihafal tiba-tiba hilang dan lupa dan harus di ulang dan di ulang lagi. Bila ditinjau lebih lanjut setiap pondok pesantren tidak semua yang bisa menjadi hafiz dan hafizoh begitu juga dengan qori dan qoriah walaupun semua santri dapat dikategorikan mampu membaca Al Qur'an dengan baik dan benar, terutam dalam pelaksanaan MTQ hanya sedikit di antara mereka yang bisa ikut berpartisipasi.

Pemberdayaan hafiz hafizoh dan qori qoriah adalah mengembangkan penguasaan keterampilan-keterampilan dasar yang relevan dengan jenis tugasnya, memperluas dan memperdalam pengetahuan-pengetahuan yang berkaitan dengan tugasnya, serta menanamkan nilainilai yang terkandung dalam setiap hal yang dipelajarinya yaitu menghafal dan memahami Al-Qur'an. Indikatornya adalah Memperhatikan niat ikhlas disaat mempelajari Al-Qur’an dan ketika membacanya, Mengamalkan kandungan Al-Qur`an, Anjuran untuk selalu mengingat Al-Qur`an dan memperbarui bacaan Al-Qur`an, Janganlah anda mengatakan: Saya telah lupa ayat atau surah Al-Qur`an akan tetapi katakanlah: Saya telah terlupakan, terjatuh hafalanku atau dilupakan dan Wajib menghayati kandungan Al-Qur`an.

\section{DAFTAR PUSTAKA}

Abdu al-Rabb Nawabudin, Metode Efektif Menghafal al-Qur'an Jakarta : CV Tri Daya Inti, 1988.

Abdul Aziz Abdul Rauf, Kiat Sukses menjadi Hafidz Qur'an Da’iyah. Bandung: Syaamil Cipta Media, 2004.

Abdul Aziz Abdul Rauf, Kiat Sukses Menjadi Hafizh Qur'an Da’iyah. Bandung : PT Syaamil Cipta Media, 2004.

Abdurrab Nawabudin, Teknik Menghafal Al-Qur'an. Bandung : Sinar Baru, 1991.

Abdurrab Nawabudin, Teknik Menghafal al-Qur'an. Bandung : Sinar Baru, 1991.

Abu Ahmadi, Startegi Belajar Mengajar. Bandung Pustaka Setia.2005.

Adnan Mahmud Hamid Laonso, Ulumul Qur'an. Jakarta : Restu Ilahi,2005.

Ahsin Sakho Muhammad, Kiat-Kiat Menghafal Al-Qur'an. Jawa Barat : Badan Koordinasi TKQ-TPQ-TQA, t.th.

Ahsin W., Bimbingan Praktis Menghafal Al-Qur'an. Jakarta : Bumi Aksara, 2000.

Al-Adzkaar hal. 160 Daar Al-Huda, cet. Ketiga $1410 \mathrm{H}$

Al-Muwaththa' Malik (320) (1/ 136) cet. Daar Al-Kitab Al-`Arabi.

Arif Armani, Pengantar Ilmu dan Metodologi Pendidikan Islam. Jakarta: Ciputat Press, 2005

Departemen Agama RI, Al-Qur'an dan Terjemahnya. Jakarta:Toha Putra, t. Th. 
George R. Terry dan Leslie W. Rue, Dasar-Dasar Manajemen. Jakarta: Bumi Aksara, 2012.

H. A. R Tilaar, Kekuasaan dan Pendidikan: Manajemen Pendidikan Nasional dalam Pusaran Kekuasaan. Jakarta: Rineka Cipta, 2009.

Hasan bin Ahmad bin Hasan Hamam, Menghafal al-Qur'an Itu Mudah. Jakarta : At-Tazkia, 2008.

Haya Ar-Rasyid dan Shalih bin Fauzan, Keajaiban Belajar Al-Qur'an. Solo: Al- Qowam, 2007.

Henry L. Sisk, Principles of Management: A System Approach to the Management Process. England: South-Western Publishing Company, 1999.

Husni Rahim, Arah Baru Pendidikan Islam di Indonesia. Jakarta: Logos, 2004.

Iskandar, Metodologi Penelitian Kualitatif. Jakarta: GP.Press, 2009.

Joko Subagyo, Metode Penelitian Dalam Teori dan Praktek. Jakarta: Rineka Cipta, 2004.

Khalid bin Abdul Karim Al-Lahim, Mengapa Saya Menghafal AlQur'an. Surakarta : Daar An-Naba', 2008

Lexi J. Moleong, Metodologi Penelitian Kualitatif. Bandung, PT.Remaja Rosdakarya, 2006.

Mahmud Yunus, Kamus Arab-Indonesia. Jakarta : Hidakarya Agung, 1990.

Malayu S.P. Hasibuan, Manajemen Dasar, Pengertian dan Masalah. Jakarta: Bumi Aksara, 2009.
Margono Slamet, Jurnal: Pemberdayaan Sumber Daya Manusia adalah Kunci Penting Meraih Mutu Organisasi, 2014.

Martinis Yamin dan Maisah, Manajemen Pembelajaran Kelas (Strategi Meningkatkan Mutu Pembelajaran). Jakarta: Gaung Persada, 2012.

Muhaimin Wazin Zenha, Pedoman Pembinaan Tahfidzul Qur;an. Jakarta: Proyek Penerangan, Bimbingan dan da'wah/Khutbah Agama Islam Pusat Ditjen Bimas Islam dan Urusan Haji Depag RI, 1982.

M.Ihsan. Dacholfany, Reformasi Pendidikan Islam Dalam Menghadapi Era Globalisasi: Sebuah Tantangan Dan Harapan, Jurnal Akademika, Vol. 20, no. 01 Jan - Juni 2015.

Nanang Fattah, Landasan Manajemen Pendidikan. Bandung: Remaja Rosdakarya, 2013.

Raghib As-Sirjani, Cara Cerdas Hafal AlQur'an. Solo : Aqwam, 2007.

Sistem Pendidikan Nasional Nomor. 20 Tahun 2003 dan Badan Standar Nasional Pendidikan (BSNP).

Sondang P. Siagian, Manajemen Sumber Daya Manusia, (Jakarta: Bumi Aksara, 2014.

Sudarman, Peningkatan Profesionalisme Tenaga Pengajar Sebagai Kontribusi Peningkatan Mutu Pembelajaran (Jurnal Pendidikan Inovatif Volume 3, 2007.

Sudarwan Danim dan Suparno, Manajemen dan Kepemimpinan Transformasional 
Kekepalasekolahan. Jakarta: Rineka Cipta, 2009.

Tafsir Al-Karim Ar-Rahman fii Tafsir Kalam Al-Mannan (2 / 112) cet. ArRiasah Al-'Ammah li-Idaraat AlBuhuts Al-'Ilmiyah wa Al-Ifta'.

Taqiyul Islam Qori, Cara Mudah Menghafal Al-Qur'an. Jakarta : Gema Insani, 1998.

Tim Guru Administrasi Pendidikan Universitas Pendidikan Indonesia, Manajemen Pendidikan. Bandung: Alfabeta, 2014.

Wina Sanjaya, Pembelajaran \& Implementasinya. Jakarta: Prenada Media. 2005. 